\title{
OR11-004 - IL-1, IL-18 and cell death in NLRP3 driven disease
}

\author{
L Broderick $^{1 *}$, SD Brydges ${ }^{1}$, MD McGeough ${ }^{1}$, CA Pena ${ }^{1}$, JL Mueller ${ }^{1}$, HM Hoffman ${ }^{1,2,3}$ \\ From 7th Congress of International Society of Systemic Auto-Inflammatory Diseases (ISSAID) \\ Lausanne, Switerland. 22-26 May 2013
}

\section{Introduction}

Missense mutations in cryopyrin (NLRP3) result in a hyperactive inflammasome that drives overproduction of the pro-inflammatory cytokines interleukin-1b (IL-1b) and IL-18. Mice expressing mutations associated with familial cold autoinflammatory syndrome (FCAS) or MuckleWells syndrome (MWS) exhibit severe, spontaneous inflammation, early death, and hyperresponsiveness to stimuli in vitro. Abrogating IL-1 signaling either genetically or pharmacologically results in modest improvement of life expectancy in murine CAPS, but clearly indicates a role for players in addition to IL-1b.

\section{Objectives}

To examine the role of other caspase- 1 dependent mediators, namely IL-18, in the context of inflammasomemediated disease.

\section{Methods}

Mice heterozygous for the A350V MWS mutation or the L351P NOMID mutation were bred to IL-1R-/- or IL18R-/- knockout mice, and weighed and assessed daily. Bone marrow macrophages and peritoneal cells were evaluated in vitro with inflammatory stimuli. Peripheral blood was drawn for complete blood counts and serum cytokine analyses. Pathology was examined in both young and old mice. Bone marrow transplant experiments were used to elucidate the role of cellular signaling compartments.

\section{Results}

Similar to IL-1b, hematopoietic cells derived from our mutant mice and monocytes from FCAS patients hypersecrete IL-18, in response to low amounts of inflammatory stimuli or cold temperature. Breeding Nlrp3 mutations onto an IL-18R null background resulted in partial

${ }^{1}$ University of California San Diego, La Jolla, USA

Full list of author information is available at the end of the article phenotypic rescue that abolished skin and visceral disease in young mice, and normalized serum cytokines to a greater extent than breeding to IL-1R null mice. However, significant systemic inflammation developed in aging Nlrp3 mutant IL-18R null mice, implicating a role for pyroptosis, a caspase- 1 mediated form of cell death. Bone marrow transplant studies demonstrate that hematopoietic cells are driving disease in murine CAPS but signaling requirements differ between IL-1 and IL-18.

\section{Conclusion}

These studies demonstrate a previously underappreciated role for IL-18 signaling in murine CAPS pathogenesis. We also confirm our previous findings that CAPS is inflammasome-dependent by demonstrating that intact caspase- 1 is required for disease, yet other downstream mechanisms besides IL-18 and IL-1b mediated inflammation are involved in this autoinflammatory syndrome constellation. Our results may have important implications for patients with CAPS and residual disease and emphasize the need to explore other NLRP3 mediated pathways and the potential for inflammasome targeted therapy.

\section{Competing interests}

L. Broderick: None declared, S. Brydges: None declared, M. McGeough: None declared, C. Pena: None declared, J. Mueller: None declared, H. Hoffman Consultant for: Regeneron, Novartis, Sobi Pharmaceuticals.

\section{Authors' details}

${ }^{1}$ University of California San Diego, La Jolla, USA. ${ }^{2}$ Rady Children's Hospital, San Diego, USA. ${ }^{3}$ Ludwig Institute of Cancer Research, San Diego, USA.

Published: 8 November 2013

doi:10.1186/1546-0096-11-S1-A193

Cite this article as: Broderick et al:: OR11-004 - IL-1, IL-18 and cell death in NLRP3 driven disease. Pediatric Rheumatology 2013 11(Suppl 1):A193.
C Biomed Central

ㄷ 2013 Broderick et al; licensee BioMed Central Ltd. This is an Open Access article distributed under the terms of the Creative Commons Attribution License (http://creativecommons.org/licenses/by/2.0), which permits unrestricted use, distribution, and reproduction in any medium, provided the original work is properly cited. 